\title{
Inter-Basin Water Diversion Projects and Inland Waterways: The Case of the Eurasian Grasslands
}

\author{
Shumin Liang ${ }^{1 *}$ and Richard Greene ${ }^{2}$ \\ ${ }^{1}$ Institute of Agricultural Economics and development, Chinese Academy of Agricultural Sciences, China \\ ${ }^{2}$ College of Geospatial Information Science and Technology, Capital Normal University, China
}

Submission: November 06, 2019; Published: November 20, 2019

*Corresponding author: Shumin Liang, Institute of Agricultural Economics and development, Chinese Academy of Agricultural Sciences, Beijing, China

\section{Abstract}

By employing the method of GIS spatial analysis, this paper plans and designs nine inter-basin water diversion projects and a Euro-Asia Canal system for the Eurasian Grasslands. The technical feasibility is analyzed for the key engineering projects. Technical and economic evaluations are calculated for nine water diversion projects. The multiple indirect benefits of these water diversion project and the canal system are elaborated. Main conclusions are that the water diversion and canal system projects are feasible; the economic benefits of the project are obvious; they can greatly promote economic development of countries along the ancient Silk Road.

Keywords: Eurasian grassland; Inter-basin water transfer project; Euro-Asia canal; Engineering technical analysis; Technical and economic evaluation; The ancient silk road

\section{Information}

Throughout the history of human development, the world's famous ancient civilizations and strong modern economies have all built advanced water conservancy projects. The latest archaeological discoveries show that the construction of the dam system in Liangzhu culture in Zhejiang Province in 3100BC may have comprehensive functions such as flood control, transportation, domestic water supply and irrigation, which is the world's first flood-controlling dam system. The Dujiang Weir and Zhengguo Canal Irrigation Project in China's Warring States Period laid the foundation for the formation of the Qin Empire. The west-east extending Grand Canal in Sui Dynasty and the south-north extending Grand Canal in Yuan Dynasty greatly promoted the prosperity and development of the ancient Chinese economy. The ancient Greek's water supply tunnel and ancient Rome's urban water supply project played an important role in the history of the world's water conservancy. With the development of international trade, the canal project in Europe recovered in the 12th century. The scientific and technological progress since the Renaissance in the mid-14th century promoted the development of water conservancy in Europe. The European canal underwent a rapid development during the period from the 16th to the 18th century, during which France, Germany and Britain dug many canals. After the 19th century, the canal mileage around the world increased rapidly, Sweden, Greece, Central Europe and Russia built the advanced canal system respectively. By the end of the 19th century, the
United States built advanced inland navigation systems with the Mississippi River as the main channel. The inter-basin water transfer project can trace its origin back to ancient Egypt's water diversion irrigation of the Upper Nile in 2400BC. However, the scale of the ancient and pre-modern inter basin water transfer projects are generally featured with small scale and short distance. The period from 1940s to 1980s is the peak of the global construction of the long-distance and large-scale interbasin water transfer projects. After the 1980s, the construction of water transfer projects in developed countries slowed down significantly, while developing countries such as India, Pakistan, Egypt and South Africa still made efforts to build water transfer projects. Up until now, the world's five major water diversion countries are Canada, India, Pakistan, the former Soviet Union and the United States [1,2]. China is gradually becoming the world's major water diversion country with the construction and implementation of the South-to-North Water Transfer Project and many provincial water diversion projects.

Among current water transfer projects around the world, the North-to-South Water Transfer Project in western North America, the North-to-South Water Transfer Project in eastern Europe and northern Asia and the South-to-North Water Transfer Project in China are the largest ones, which have all been proposed and studied in academia earlier with specific design, and are partly implemented. In 1968, Ralph M. Parsons Company in Los Angeles proposed a large-scale inter-basin water transfer project- the 
North American Water and Power Alliance (NAWAPA), of which the investment in that water transfer is equivalent to $26.14 \mathrm{CNY}$ per cubic meter with the exchange rate in 2016. The internal rate of return (IRR) is $4.36 \%[3,4]$ calculated by the Economics department in San Jose State University. However, the project was not implemented under the opposition of the environmental and anti-dam movements [5]. Later, the plan was improved, and the quantity of water diversion was increased [6-8]. In the early 1980s, Gordi, a water conservancy engineer of the Former Soviet Union, proposed a water transfer plan that transferred water from the $\mathrm{Ob}$ River to the Syr River and the Amu River through the Tobol River, which was terminated due to the breakdown of the Soviet Union. However, with the intensified water resource crisis in Central Asia, Kazakhstan proposed to continue the investigation of the Siberian-Central Asian water transfer project [9-14]. In China, Mao Zedong first developed the idea of the South-to-North Water Transfer Project in 1952. At present, the overall plan of the Eastern Route, Central Route, and Western Route of the project has been finished. Among which, the pumping and diversion project for the Eastern Route started to operate in 2013, and the first phase of gravity flowing water transfer project for the Central Route was completed in 2014. The construction of the Western Route has not started yet at present day, and various alternative schemes for this route have been proposed by experts in recent years [15-18], including the Hongqi He (the Red Flag Canal) which was proposed in November , 2017.

The terrain, climate and hydrological characteristics of the Eurasian Grassland and its vicinity areas are conducive to the construction of inter-basin water transfer projects and inland navigation networks. With the main purpose of guaranteeing the global food supply, this paper designs the possible interbasin water transfer project with the maximum scale in Eurasian Grassland based on existing researches. In order to accomplish the comprehensive development of the regional economy of central Eurasia, this paper provides engineering and technical schemes for the following aspects: the development and utilization of the abundant water and land resources of the Eurasian Grassland and its surrounding areas, the development of irrigation agriculture, the construction of large-scale irrigation agricultural areas. This paper also takes into account the canal building for navigation, hydropower generation, mining and industrial water use, urban and residential water use, and ecological water demand. Based on the basic principles of the nearest distance water diversion, gravity flow water diversion, and current engineering and technical feasibility, this paper focuses on the study of nine major inter-basin water transfer projects in the following three regions: the North-to-South water transfer project in eastern Europe and north-central Asia, the South-to-North water transfer project in China, and the Northto-South water transfer project in northeast Asia, which can be collectively called the Eurasian Grassland Water Transfer Project. Initial evaluation of these nine projects in terms of their engineering and technical feasibility, technical and economic benefits, social benefits, ecological and environmental impact and other aspects is conducted. In addition, based on the water diversion project, this paper also designed the Eurasian inland navigation project, to develop the navigation through utilizing water diversion channels and natural waterways, to build the canal connecting the Eurasian Grassland and oceans, and to connect with the current inland navigation network in Europe.

\section{Designing the Water Transfer Lines and Canal Net-} works

\section{Designed nine water transfer lines}

The overall principle of the inter-basin water transfer project design is based on the current level of engineering technology and with the purpose of achieving maximum water diversion benefits, which manifests mainly in 10 aspects: gravity flowing water transfer, nearest distance water transfer, taking agriculture as main destination, water-saving irrigation, recycling water use, hydro-power generation, canal navigation, flood control, ecological friendly, and technically feasible. In accordance with these principles, the Eurasian Grassland interbasin water transfer project can be divided into nine lines and their detailed description are as follows.

Line 1 refers to the eastern route and central route of China's South-to-North Water Transfer Project, with the North China Plain as the destination area and the water-source region including the middle and lower reaches of the Yangtze River, the middle and lower reaches of Bailong River, the upper reaches of the Jialing River and the Han River. The starting points of this line are the Danjiangkou Reservoir of the Han River, which is 147 meters above sea level, and the Yangzhou section of the Grand Canal, which is 2 meters above sea level. The eastern line transfers water to the north from the Yangzhou section of the Grand Canal, along which the highest point is the Dongping Lake with the elevation of 40.5 meters, and the end of the main canal is the Tianjin Beidagang Reservoir with the elevation of 7 meters. As for the central line, the extended water-source region is the Three Gorges Reservoir, whose normal water level is 175 meters above sea level, and the end of the main canal is Beijing's Tuancheng Lake in the Summer Palace with the elevation of 49 meters.

Line 2 refers to the western route and its extension of the South-to-North Water Transfer Project and the Great Western Line, with the Loess Plateau, the Hanhai Basin, western part of the Liaohe River Basins, the Hexi Corridor, the Tarim Basin, the Junggar Basin and the Balkhash Lake as the destination area. The water-source region includes the upper reaches of the Yaluzangbu River, the upper reaches of the Nu River (Salween), the upper reaches of the Lancang River, the Jinsha River, the Yalong River, the Dadu River, the Min River, the upper reaches of the Bailong River, the Tao River, the upper reaches of Yellow River, the Huangshui River, the Datong River and the Zhuanglang 
River, among which one of the furthest water-source reservoir is the Sangbai Reservoir in Milin County along the Yaluzangbu River with the normal water level of 3180 meters in Tibet. The starting points of this line are the Minxian section of the Tao River, the Jiudianxia Reservoir of the Tao River and the Liujiaxia Reservoir of the Yellow River, with the elevation of 2320 meters, 2232 meters and 1735 meters respectively. For the western ends of the main canal, they are the Lake Balqash in Kazakhstan with the elevation of 450 meters, the end of southern Xinjiang canal's northern branch with the elevation of 1020 meters, the end of southern Xinjiang canal's southern branch with the elevation of 1500 meters; for the eastern ends of the main canal, they are Inner Mongolia's Ordos direction with the elevation of 1150 meters, Inner Mongolia's Huolin Gol direction with the elevation of 950 meters, Mongolia's Dornogovi (Eastern Gobi) province direction with the elevation of 960 meters.

Line 3 refers to the Qaidam line of the South-to-North Water Transfer Project, with the Qaidam Basin as the destination area, and the water-source region including rivers and inland lake basins (Kekexili and Western Qaidam) on the northern slope of the Kunlun Mountains, with elevation above 4000 meters normally. The starting points of this line are the reservoirs of the Golmud River and the Nalinguole River, with the normal water level of 3400 meters and 3300 meters above sea level respectively. And the end of the main canal that goes around the basin is 2,800 meters above sea level.

Line 4 refers to China's northeast line of the North-to-South water transfer project in northeast Asia, with the Northeast China Plain as the destination area. Its water-source region includes the Shilka River, the upper reaches of the Heilong River (Amur) and tributaries along its right bank. The water source is Taozi Reservoir in Mohe County, Heilong Jiang, with an elevation of 360 meters. As the starting point of this line, the elevation of Nen River's Sizhan Reservoir is 300 meters. The end of main canal is the Daling River in Yi County, Liaoning province, with an elevation of 220 meters. The northern section of this line overlaps with the post road stretching north from Nenjiang City to Mohe County, built in the Kangxi period of the Qing Dynasty.

Line 5 refers to the Hulun Lake line of the North-to-South water transfer project in northeast Asia, with the Hulunbuir Plateau as the destination area, and the water-source regions that include the rivers along the west slope of the Greater Xingan Range (the Jiliu River, the Gen River, the Hailar River, the Halaha River) and the rivers along the northwestern part of Hulun Lake (the Kherlen River, the Urez River, the Onon River, the Vitim River). The starting points are the piedmont reservoirs on the rivers mentioned above. As for the elevation of the water-source reservoir, the starting point and the end of the main canal, they were 800 meters, 650 meters and 600 meters respectively for the Jiliu River- the Gen River line; 730 meters, 710 meters and 700 meters for the Hailar River line; 850 meters, 780 meters and 760 meters for the Halaha River line; 700 meters, 670 meters and 650 meters for the Vitim River; 900 meters, 890 meters and 880 meters for the upper reaches of the Onon River line.

Line 6 refers to the Mongolia Gobi line of the North-to-South water transfer project in northeast Asia, with the Mongolian Gobi as the destination area. Its water-source region includes the Zhida River, the Eg River (Egiin Gol), the Selenga River, the Orkhon River. The elevation of the Zhida River Reservoir is 1251 meters. The Khangai Mountains tunnel, as the starting point, is 1231 meters above sea level. And the end of the main canal is at an elevation of 1080 meters in southern Mongolia.

Line 7 refers to the Turan lowland's upper line of the North-to-South water transfer project in central and north Asia, with the Turgay highland and the eastern Turan lowland as the destination areas. The water-source region includes the Kizilirmak River, the upper reaches of Yenisey River, the Abakan River, the upper reaches of the Ob River and the Ergis River. The elevation of the Kizilirmak River Reservoir, as the furthest water source, is 569 meters. The starting point of this line, Oskemen Reservoir on the Ergis River is 388 meters above sea level. And the end of the main canal is at an elevation of 280 meters in Turkmenistan.

Line 8 refers to the Turan lowland's lower line of the Northto-South water transfer project in central and north Asia, with the Kulunda Plain, the Ishim Plain, and the western Turan lowland as the destination areas. The water-source region includes the Lena River, the middle and lower reaches of the Selenga River, the Lake Baikal, the Angara River, the Oka River, the Cune River, the Mana River, the Chulym River, the Tom River, the Ob River and the Ergis River. The furthest water source, the Lena River Reservoir is 509 meters above sea level. The starting point of this line is the Shulbinsk Reservoir on the Ergis River with an elevation of 259 meters. The end of the main canal is at an elevation of 120 meters in Turkmenistan.

Line 9 refers to the Caspian-Aral line of the North-to-South water transfer project in the eastern part of Europe, with the Caspian-Aral lowland as the destination area. The water-source region includes the upper reaches of the Enba River and the Uil River, the Ural River, the upper reaches of Maly Uzen, the Volga River and the Don River. The starting points of this line are the Don-Volga Canal, the Volgograd Reservoir, the Volsk Reservoir, the Orenburg Reservoir at the upper reaches of the Ural River. As for the elevation of the water-source reservoir, the starting point and the end of the main canal, they are 110 meters, 30 meters and 0 meters for Volga River; 130 meters, 10 meters and 0 meters for Don River; 245 meters, 70 meters and 55 meters for the Ural River.

According to the laws of water vapor evaporation and movement within the Eurasia Continent [19], the multiplier effect of evaporation is large when transferring water to upwind areas. Three North-to-South water transfer projects in north central Asia and Eastern Europe transfer runoff from southern 
Siberia to central Asia located in the southwest. Irrigation would therefore be developed in the Caspian lowland and Turan lowland, the water vapor generated is in the upwind position of the westerlies, the multiplier effect of irrigation evaporation is large, so that the inter-basin water transfer could form a virtuous circle. The Western Route and its extension, and the Great Western Route of China's South-to-North Water Transfer project, transfer water from the southwest monsoon region in southwestern China to the arid area of northwestern China along the east and northeast margin of Tibetan Plateau. Runoff in the southwest monsoon region are fully used to increase the water vapor supply in inland areas, so that the water resources supply in mainland China can be greatly increased through the multiplier effect of water vapor evaporation. A virtuous cycle can also be formed with stable sustainability.

\section{Eurasia grassland's canal networks}

Based on the inter-basin water transfer project, natural channels and connected canals will be established at key sections to form the Eurasia inland waterway network, taking the Eurasia grassland as the core region. Through trunk canals, natural channels and current canal systems, as well as building key canals and ocean passageways, the Eurasia inland waterway network planned in this part forms an inland waterway network, which connects Europe and Asia, as well as the Pacific Ocean, Atlantic Ocean and Indian Ocean. The planned canal and waterway regulation projects in this part belong to the extended section of water transfer projects on the Eurasian grassland, the cost-benefit accounting can be calculated independently and would not be involved in the cost-benefit accounting of water transfer projects on the Eurasian grassland. The extended projects have a total length of $57,132 \mathrm{~km}$, which mainly includes the Mediterranean waterway, Caspian Sea waterway and current European inland waterways, as well as new waterways to be built, such as the Caspian Sea-Black Sea waterway, Caspian SeaIndian ocean waterway, Mediterranean-Persian Gulf waterway, inland to ocean waterway of the Yellow River, inland to the ocean waterway in Northeast China and the Inner Mongolia Plateau, inland to the ocean waterway in Siberia, Russia.

Two ocean passageways in the Sanjiang Plain of northeastern China. At present, there are inland waterways running into the Okhotsk Sea through the Heilong River, Wusuli River, and the Amur River. The ocean passageway of the Songhua River - Suifen River could be built. In this project, a canal would be excavated from the south bank of the Songhua River (85 meters above sea level) in Tangyuan County, Heilongjiang Province to the southeast direction, and then it stretches to the south direction through Jiamusi, Shuangyashan, Youyi and Baoqing with the elevation of the canal reducing to 80 meters. The canal would be excavated to Hulin by cutting through a hill with a maximum elevation of 112 meters and connecting Xingkai Lake with an elevation of 64 meters. The canal elevation declines to 59 meters after cutting through a hill with an elevation of 100 meters in the south. It will converge with the runoff coming from a reservoir on the Suifen
River, and finally it runs south into the Sea of Japan. Meanwhile, the newly built Xingkai Lake canal can connect the Sanjiang Plain and the Sea of Japan, through which the ships can run into the ocean by going through the upper stream of the Wusuli River, Xingkai Lake, and the Suifen River.

Ocean passageways of the Yellow River. Three inland channels go to the east in the middle reach and seven ocean passageways connect the ocean in the lower reach of the Yellow River. In the northwest main canal stretching from Liujiaxia Reservoir to Gansu's Hexi Corridor, a steep canal would be excavated at the elevation of 1,710 meters, located in Manshuitan, Jingtai county, Gansu Province, stretch to the east and flow into the Yellow River at Shapotou with an elevation of 1,239 meters in Zhongwei City, Ningxia. Then by following the Yellow River, the channel's elevation reduces to 110 meters at the Taohuayu in Zhengzhou, Henan Province, after running through the Qingtongxia Water Control Project, Sanshenggong Water Control Project, Wanjiazhai Reservoir, Hukou Waterfall, Sanmenxia reservoir and Xiaolangdi reservoir. Along this channel, 36 navigation locks would be built. A canal needs to be excavated to the east on the steep canal running from northwest main canal to the Yellow River at the elevation of 1,460 meters. Two aqueducts, with a length of 853 meters and 969 meters respectively, would be built above the Daliushu Dam on the Yellow River at the elevation of 1,455 meters. When it stretches east to Changshantou Township, an aqueduct with an elevation of 1,450 meters and length of $13 \mathrm{~km}$ would be built over Qingshui River Valley, the canal elevation will decline to 1,445 meters at the north of Daluo Mountain and 1,440 meters at Mengcheng, Yanchi County, Ningxia. A navigable tunnel of $16.7 \mathrm{~km}$ would be excavated to connect Xichuan River (upper stream of Huan River) at Huanxian County, Shaanxi Province, Huan River and the Jing River would need to be canalized for navigation. Then it flows into the Yellow River through Wei River at the elevation of 325 meters. Twenty-five navigation locks would be built on the canalized channel. A canal can be built running upstream of the Dusitu River from the Yellow River at the elevation of 1,090 meters at Pingluo, Ningxia. The canal turns to the south at the elevation of 1,350 meters, then runs along the eastern contour line of the open valley located at the southwest of the Maowusu sandy land, and it connects upstream of the Wuding River at the east of the joint boundary point of Gansu, Ningxia and Inner Mongolia. After that, it follows Wuding River and runs into the Yellow River at the elevation of 590 meters. Twenty-three navigation locks would be built between the estuaries of the Dusitu River and the Wuding River. The above three channels can form the shipping corridors on the Loess Plateau. Among them, the Yellow River main channel has a long history of navigation and the government already has plans for channel development, so it has the advantage to be built first. The Jinghe channel is a shortcut which takes advantage of the water transfer project as it runs directly to the east from Manshuitan, which could be built as the main channel for the Eurasian canal. 
Seven canal passages connecting the Yellow River with the ocean can be built downstream from the Xiaolangdi Reservoir. One running through Zhengzhou, Kaifeng, Jinan, along the main channel of the Yellow River, and entering the Bohai Sea at Kenli County, Shandong province. The second excavates a canal at Huayuankou, Zhengzhou, Henan Province on the south side of the Yellow River to connect the Jialu River, and then runs through the Ying River, Huai River, Dongfei River; excavating a canal to connect Chaohu Lake, and then enters the East China Sea through the Yuxi River and the Yangtze River. A third canal excavation would be at the south side of the Yellow River which would connect the Huiji river and run through the Wo River, Huai River and Hongze Lake; excavating a canal at the east bank of the Jinhu Lake to connect the Yellow Sea through Baoying, Yancheng and Xinyang harbor. Fourth would be excavating a canal at Lankao on the south side of the Yellow River, where it runs into the Yellow Sea through the South Grand Canal and the Xinyi River. A fifth canal excavation would be at Zhengzhou on the north side of the Yellow River to connect the People's Victory Canal, which runs into the Bohai Sea at Tianjin through the Weihe River, South Grand Canal and the Hai River. The sixth canal excavation would be on the Weihe River to the north from the Dongfeng River of Weixian, Hebei province, which runs into the Bohai Sea at Tianjin through the Fuyang River, Ziya River and Haihe River. A seventh project would build a canal flowing north from the South Grand Canal at Taiqian County, Henan province, where it connects the Majia River at Liaocheng City, Shandong Province and runs into the Bohai Sea. Among these seven channels, the Ying River Channel is conductive to transporting grain and agricultural products to southern China. Harbors along the channel have good conditions, and Anhui province has a plan to transfer water from Yangtze to Huaihe River, which can be utilized as a main channel.

Three ocean passageways for the Inner Mongolia Plateau. One channel starts from the Shandian River of Inner Mongolia at the elevation of 1310 meters and enters into the Bohai Sea through the Luan River. 29 navigation locks would be built along this channel. The second channel starts from the lowest point of watershed range between Dalai Nar Lake and Xilamulun River at the elevation of 1300 meters in Keshiketeng Banner, Inner Mongolia, then flows to the east along the Xilamulun River and enters into the Bohai Sea at Yingkou City through Xiliao River and Liao River, 27 navigation locks would be built along this channel. The third channel starts from the lowest point of watershed range between Wulagai River and Huolin River at the elevation of 947 meters in Holingol City, Inner Mongolia. It runs to the southeast along the Huolin River and runs to the south along Songliao Canal, and then enters into the Bohai Sea at Yingkou through West Liaohe River and Liaohe River. 19 navigation locks would be built along this channel. Among the three channels, the Luanhe Channel has a smooth path and navigation history, so that it is the main channel connecting Inner Mongolia Plateau to the Pacific Ocean.
There are three ocean passageways for Siberia. One channel starts from the Angara River at Siberia and runs south through the Selenga River, Orhon River, Mongolia's Gobi canal, on the northern foot of the Yinshan Mountains and the Luan River, which is the most convenient channel to enter the sea, it is also the main channel for Siberia to enter the sea. The main channel extends northward from the Angara River to the Yenisei River through the Bratsk Reservoir, or connects the upstream and midstream of Vitim River and Lena River, which could stretch the inland waterways to the vast hinterland of Siberia. A canal excavated from the eastern branch of Mongolia's Gobi canal to connect with Baer Lake, which forms the second ocean passageway by running through to the Wuerxun River, Hulun Lake, Erguna River and Heilong River, and finally entering into the Japanese Sea or the Okhotsk Sea. The North-to- South water transfer project at Northeast Asia can also form a third channel, running southward from the Vitim River to Hulun Lake, while a large diameter navigation tunnel shall be excavated.

Channels connecting the Caspian Sea and the Indian Ocean. In the upstream of the Kizil Uzan River, a tunnel can be excavated to connect the Diyala River, and another tunnel can be excavated to connect the Karkheh River, where a canal can be excavated near Ahvaz to connect the Karen River and that will flow into the Persian Gulf through the Arabia River. The channel is a program for the Caspian Sea-Persian Gulf Grand Canal jointly planned by Russia and Iran. Alternatively, in the upstream of the Kura river and Aras River, a tunnel can be excavated to connect the north end of Orumiyeh Lake at the elevation of 1,267 meters; a tunnel would be excavated in the south of the lake to connect Lesser Zab, where it will run into the Persian Gulf after running through the Tigris and the Arabia rivers. Fifty-six navigation locks would be required. The Orumiyeh Lake channel has a lower elevation and a convenient path that connects four countries, so it can be built as the main channel.

Two channels connect the Caspian and Black seas. Ten meters upstream from the Volga Estuary in the Caspian Sea, the channel runs through Astrakhan to south Volgograd, and then enters the Don River via the Volga River-Don River canal with a maximum elevation of 80 meters, and then it finally enters the Black Sea at Rostov, Russia. This channel has been built and is the main channel of the Eurasian canal. In the upstream of the boundary of Russia's Kalmykia and Dagestan (elevation -10 meters), a canal could be built along the Mancini Graben with the highest elevation of 25 meters. It finally enters the Black Sea at Rostov after running through the Proletarian reservoir and Mancini River. The channel has the advantage of a low elevation, and is easy to construct, which has great potential for development.

Three channels link with the Atlantic Ocean. Channels connecting the Mediterranean, Black sea, Caspian Sea and the Atlantic Ocean are as following: Mediterranean-Gibraltar Strait channel; Dnieper River - Canal- Vistula River-Canal- Oder River -Canal-Port of Hamburg on Elbe River at Germany; Caspian Sea - 
Volga River-Onega Lake- Ladoga Lake-Saint Petersburg at Russia. All of these Atlantic channels and ports across the European continent have been built. In order to facilitate the east-west direction of the inland waterways of Eurasia, a canal from the Sea of Azov to the Dnieper River shall be built (Figure $1 \& 2$ ).

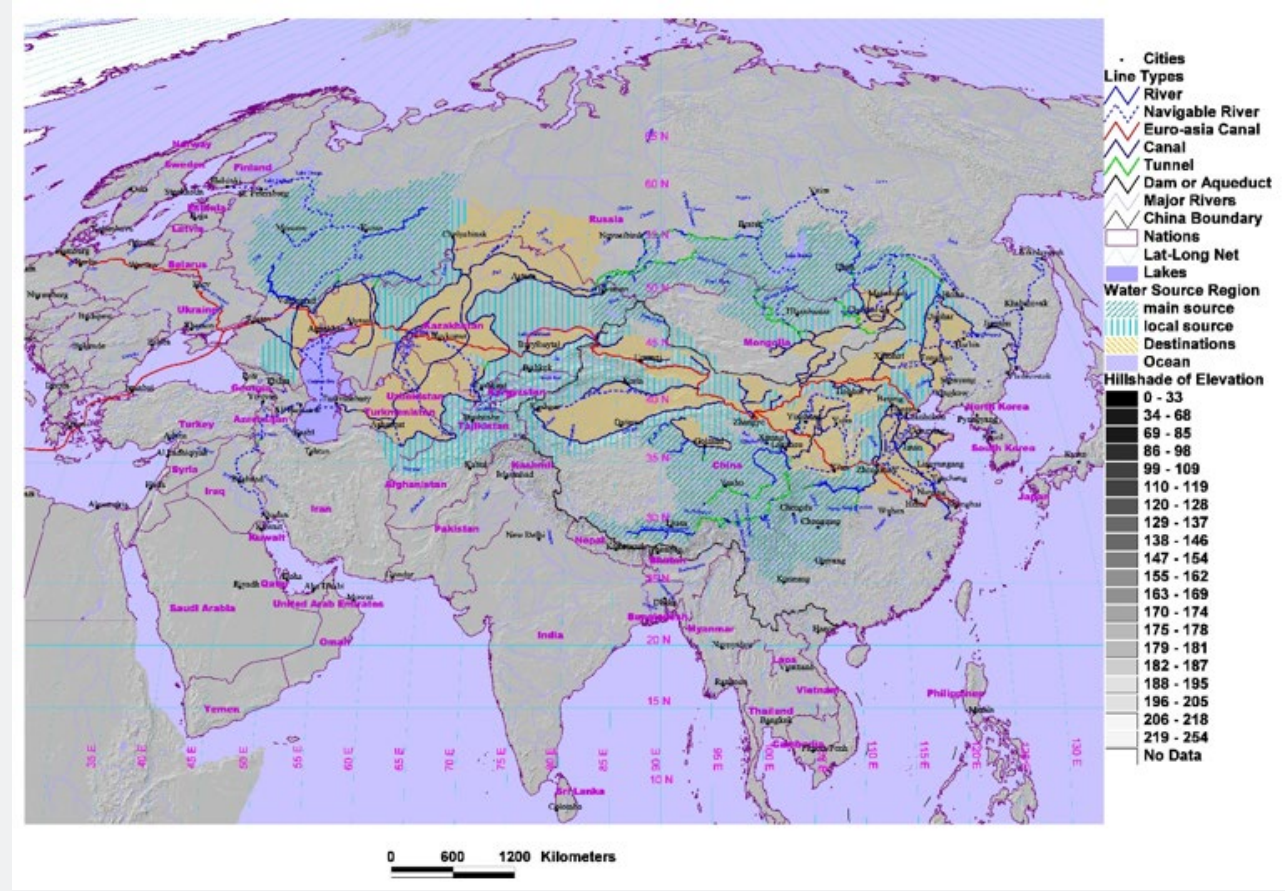

Figure 1: Sources and destinations of the Eurasian grassland's water diversion project.

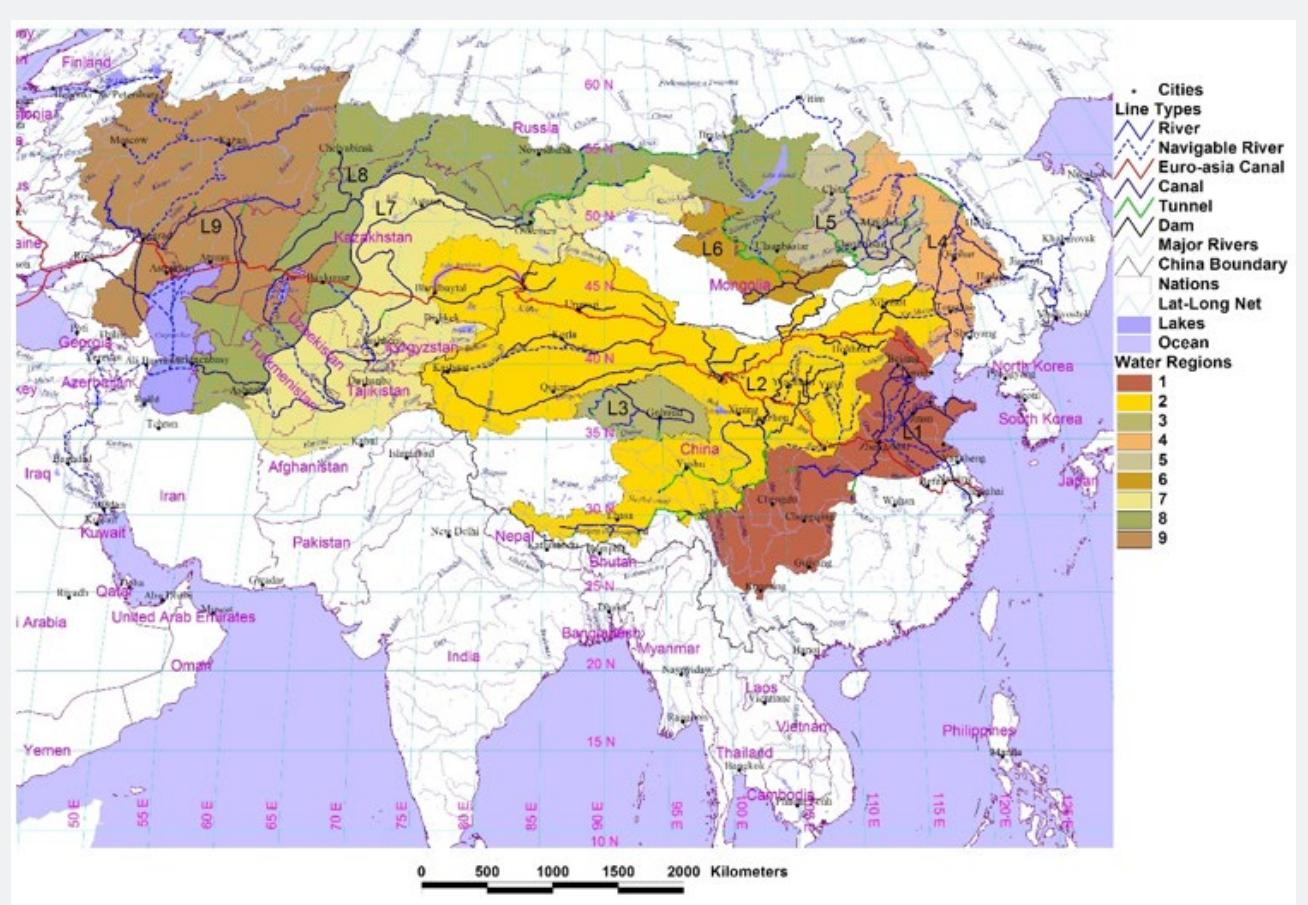

Figure 2: Nine regions of the Eurasian grassland's water diversion projects.

The main channels of the Eurasian inland waterway in this paper are dumbbell-shaped with a total length of $17,576 \mathrm{~km}$. Among them, the section from Zhangye, China to Rostov, Russia is the central axis with a total length of $6,880 \mathrm{~km}$, which is the core section of the Eurasian Canal. To the Northeast, it connects the east piedmont of the Yabulai Mountain-north piedmont of Yinshan Mountain-Luanhe River Channel and enters the Bohai Sea; to the southeast, it connects the Jinghe river- the Yellow 
River - Yinghe River - the Yangtze River Waterway and enters the East China Sea; to the northwest, it connects the Dnieper River -Vistula River-Oder river-Elbe River Water- way and Exploitation Potential and Engineering Technology Analysis

\section{Exploitation potential of water transfer}

Table 1: Volume of water resource for destination regions in the Eurasian Grassland, 100 million cubic meters.

\begin{tabular}{|c|c|c|c|c|c|c|}
\hline Destination Regions & $\begin{array}{c}\text { Area } \\
10000 \mathrm{~km}^{2}\end{array}$ & $\begin{array}{c}\text { Water } \\
\text { Transferred }\end{array}$ & $\begin{array}{c}\text { Local Mountain } \\
\text { Runoff }\end{array}$ & $\begin{array}{l}\text { Local Plain } \\
\text { Runoff }\end{array}$ & $\begin{array}{c}\text { Total Water } \\
\text { Available }\end{array}$ & $\begin{array}{c}\text { Total Water } \\
\text { Demand }\end{array}$ \\
\hline North China Plain & 36.7 & 539 & 542 & 674 & 1755 & 2332 \\
\hline Northwest China \& Inner Mong. & 182.3 & 2129 & 1006 & 929 & 4188 & 11568 \\
\hline Qaidam Basin & 7.6 & 55 & 69 & 8 & 131 & 361 \\
\hline Northeast Plain & 24.4 & 144 & 333 & 300 & 778 & 243 \\
\hline Hulun Lake & 14.9 & 161 & 77 & 86 & 323 & 107 \\
\hline Gobi Desert & 10.1 & 133 & 35 & 24 & 191 & 306 \\
\hline Turgay-Turan east & 75.6 & 1612 & 1796 & 235 & 3643 & 6245 \\
\hline Kulunda-Turan west & 124.8 & 1623 & 194 & 866 & 2682 & 4156 \\
\hline Caspian and Aral & 56.7 & 2523 & 385 & 155 & 3063 & 3828 \\
\hline Total & 533 & 8918 & 4437 & 3276 & 16755 & 29146 \\
\hline
\end{tabular}

Based on the Miami model [20], according to the mean annual precipitation and mean annual temperature [21], light-temperature and climate potential productivity can be calculated, as well as the amount of irrigation water required to reach the temperature potential productivity, which is acquired by subtracting precipitation from water demand to achieve the temperature potential productivity; the amount of available water resources in the destination area can be calculated by adding up the amount of inter-basin transferred water, runoff volume (mainly underground runoff) from the destination area, and runoff volume from the destination area's upstream mountains. With the amount of irrigation water required to reach the light-temperature potential productivity and available water resources amount in the destination area, a reclamation ratio and area of arable badlands available for irrigation and reclamation can be calculated for the destination area. The Eurasian grassland covers a total area of 5.3295 million square kilometers, which is 3.2 times the area of Xinjiang, China. The amount of transferred water is 891.78 billion cubic meters, which is close to the annual average runoff of 893.1 billion cubic meters at the Datong hydrological station of the Yangtze River. The amount of transferred water, the runoff of 443.68 billion cubic meters from the mountains of the destination area and the runoff of 327.62 billion cubic meters in the destination area itself, totally reach an amount of 1675.48 billion cubic meters as water resource available for irrigation (Table 1). The runoff from the water source area is based on the GRDC data [22]. With GIS grid data and the use of spatial analysis functions, the runoff data from the destination area and its mountainous regions can be acquired and calculated by an empirical formula according to the ground slope, aridity index, and annual precipitation $[23,24]$. Finally, the runoff volume of the destination area and its mountainous region is acquired through area summarization. enters the North Sea; to the southwest, it connects the Black SeaMediterranean waterway and finally reaches Rome.
According to the target irrigation reclamation ratio, all of the nine destination areas can irrigate 4.452 billion mu (1/15ha) of cultivated land, minus the existing 1.817 billion mu of farmland in the destination area with a net increase of 2.635 billion mu, which accounts for $10.15 \%$ of the world's total, 25.94835 billion $\mathrm{mu}$. Among them, 964.7 million mu can be increased from the six projects of China and Mongolia's destination area, accounting for $47.62 \%$ of China's 2.02586 billion mu cultivated area in 2015.

The temperature potential productivity in the natural ecosystem is highly correlated with the grain yield from the irrigated farmland ecosystem. According to the author's experience, the latter is estimated to be 0.7 times of the former; the grain yield of the irrigated farmland ecosystem also has a high positive correlation with its oilseed yield, the former is estimated to be 2.3 times of the latter. Based on the area of wasteland available for irrigation and reclamation in the destination area, grain and oilseed yield in the irrigated farmland ecosystem, as well as the area proportion and yield of existing cultivated area, we can estimate the potential yield increase of grain and oilseed with transferred water in the destination area, including the yield-increasing potential of the current cultivated land and wasteland irrigated and reclaimed in the destination area. The total grain and oilseed output potential of the destination areas is 1,830 million tons, of which 382 million tons are produced by the current cultivated land. After being irrigated by the transferred water, a total increase of 1,449 million tons can be achieved, including 394 million tons from the current cultivated land and 1,055 million tons from the newly irrigated and reclaimed land, accounting for $35.70 \%$ of the 2015-2016 global grain and oilseed output of 4,059 million tons. Output can be increased by 565.2 million tons in China and Mongolia's destination area, taking up $86.6 \%$ of the 2016 China's grain and 
oilseed output of 652.37 million tons. The output increased in Northwestern China and Inner Mongolia is 376 million tons, slightly exceeding the 332 million tons estimated by the author Table 2: Land reclamation potential and agricultural production capacity, $100 \mathrm{mmt}$ : 100 million metric tons.

\begin{tabular}{|c|c|c|c|c|c|}
\hline Destination Regions & $\begin{array}{c}\text { Target } \\
\text { Reclamation Rate }\end{array}$ & $\begin{array}{c}\text { Farmland Area can } \\
\text { be Irrigated, 100 } \\
\text { million } \mathbf{~ m u}\end{array}$ & $\begin{array}{c}\text { Farmland can be } \\
\text { increased, 100 } \\
\text { million mu }\end{array}$ & $\begin{array}{c}\text { Total Grain \& Oilseed } \\
\text { Output, 100 mmt }\end{array}$ & $\begin{array}{c}\text { Grain and Oilseed } \\
\text { Output can be } \\
\text { increased, 100mmt }\end{array}$ \\
\hline North China Plain & 0.608 & 3.35 & 0 & 2.26 & 0.63 \\
\hline $\begin{array}{c}\text { Northwest China \& } \\
\text { Inner Mong. }\end{array}$ & 0.351 & 9.61 & 6.45 & 4.47 & 3.76 \\
\hline Qaidam Basin & 0.364 & 0.41 & 0.41 & 0.14 & 0.14 \\
\hline Northeast Plain & 0.8 & 2.93 & 0.29 & 1.23 & 0.47 \\
\hline Hulun Lake & 0.8 & 1.78 & 1.55 & 0.47 & 0.41 \\
\hline Gobi Desert & 0.624 & 0.94 & 0.94 & 0.23 & 0.23 \\
\hline Turgay-Turan east & 0.583 & 6.61 & 6.01 & 2.94 & 3.73 \\
\hline Kulunda-Turan west & 0.646 & 12.09 & 4.48 & 2.82 & 3.79 \\
\hline Caspian and Aral & 0.8 & 6.8 & 6.21 & 18.3 & 2.79 \\
\hline Total & 0.557 & 44.52 & 26.35 & & 14.49 \\
\hline
\end{tabular}

\section{Engineering technology analysis}

The Eurasian Grassland inter-basin water transfer project, including trunk canal, natural waterway, Eurasian canal, tunnel and bridge, river deepening excavation, aqueduct, wind power pumping and dam, can serve for both water supply and inland navigation. The Total length of the single line is 70,037 kilometers (including length of the dam), which mainly consists of $31,421 \mathrm{~km}$ of trunk canal, $21,765 \mathrm{~km}$ of natural waterway, $10,000 \mathrm{~km}$ (excluding natural waterways) of the Eurasian canal (Atlantic - Pacific Canal). The length of the tunnel (bridge) along the single track is $7,082 \mathrm{~km}$. It is necessary to build multiple before [25]. By applying the Miami model to calculate the output potential, this research is more accurate and reliable (Table 2). track tunnels in areas with large flow of transferred water. According to the quantity of water flow, it is estimated that the total lengthen for the multiple track tunnel and bridge is $25,175 \mathrm{~km}$. Therefore, the construction length of the single track is $48,272.2 \mathrm{~km}$, while that of multiple tracks is $66,365 \mathrm{~km}$. With the addition of extending the project, the overall length will be $145,262 \mathrm{~km}$, about 3.62 times the length of Equator (Table 3). It is truly a mega-project. But in comparison, the operational mileage of China's high-speed railway in early 2017 (started form 2008) is $22,000 \mathrm{~km}$, and China's expressway is $130,000 \mathrm{~km}$ (started form 1984).

Table 3: Construction cost estimation, $100 \mathrm{mcm}$ : 100 million cubic meters

\begin{tabular}{|c|c|c|c|c|c|c|}
\hline $\begin{array}{l}\text { Destination } \\
\text { Regions }\end{array}$ & $\begin{array}{l}\text { Dams to } \\
\text { be Built }\end{array}$ & $\begin{array}{l}\text { Length of all Lines } \\
\text { to be Built, km }\end{array}$ & $\begin{array}{l}\text { Compound Length to } \\
\text { be Built, km }\end{array}$ & $\begin{array}{c}\text { Cost of Water } \\
\text { Transfer 100mil CNY }\end{array}$ & $\begin{array}{c}\text { Volume of Water } \\
\text { Transferred, } 100 \mathrm{mcm}\end{array}$ & $\begin{array}{l}\text { Unit Cost, } \\
\text { CNY/m3 }\end{array}$ \\
\hline North China Plain & 8 & 3711 & 4245 & 5713 & 539 & 10.6 \\
\hline Northwest China & 38 & 18382 & 24945 & 33571 & 2129 & 15.8 \\
\hline Qaidam Basin & 2 & 1444 & 1444 & 1943 & 55 & 35.4 \\
\hline Northeast Plain & 8 & 2501 & 2501 & 3366 & 144 & 23.4 \\
\hline Hulun Lake & 10 & 2252 & 2252 & 3030 & 161 & 18.9 \\
\hline Gobi Desert & 8 & 2514 & 2514 & 3383 & 133 & 25.5 \\
\hline Turgay-Turan east & 19 & 6253 & 9836 & 13237 & 1612 & 8.2 \\
\hline $\begin{array}{l}\text { Kulunda-Turan } \\
\text { west }\end{array}$ & 23 & 6798 & 13073 & 17593 & 1623 & 10.8 \\
\hline Caspian and Aral & 3 & 4418 & 5557 & 7479 & 2523 & 3 \\
\hline Total & 119 & 48272 & 66365 & 89316 & 8918 & 10 \\
\hline
\end{tabular}

The former has built $22,000 \mathrm{~km}$ within 9 years while the later $130,000 \mathrm{~km}$ in 33 years, finishing 6,384km annually during its simultaneous construction period; the construction length of the multiple track in this project is $66,365 \mathrm{~km}$. With a construction period of 30 years, it is estimated to build $2,212 \mathrm{~km}$ annually, the intensity of which is only a little more than one-third of the above two projects. Given the six main participant countries of China,

Russia, Kazakhstan, Uzbekistan, Turkmenistan and Mongolia, the project is within the joint comprehensive national strength and engineering and technology capacity of construction.

Dam: The Eurasian Grassland water transfer project needs to build 119 dams. Dam construction is the key project, including mostly high dams and long dams, some of which are situated in high seismic intensity regions. Most of the high dams are 
along the West and Great west line of the South-to-North water diversion in China. The V-shaped valley is typical at the southeast edge of the Qinghai-Tibet Plateau. Considering the current technology development of high dam construction, the designed height limit of high dams is $315 \mathrm{~m}$. To bypass the Jiuzhaigou and Huanglongsi Nature Reserve, keep constant longitudinal canal slope and shorten the length of the dam on Yaluzangbu River, the Great West Route's dam and diversion tunnel are moved to the upstream slightly. Main changes include: height of Bailong River's Ni'ao Dam is shortened from $320 \mathrm{~m}$ to $298.2 \mathrm{~m}$ as Kaba Dam; height of Shuangjiankou dam on Dadu River is changed from $329 m$ to a $286.4 m$ at Baiwan, Maerkang County, Sichuan Province; height of Langyu Dam in Yigongzangbu is changed from $301 \mathrm{~m}$ to $306.4 \mathrm{~m}$; dam on Yaluzangbu River is changed from $231 \mathrm{~m}$ at Biding to $218 \mathrm{~m}$ at Sangbai, and the dam length is shortened from $2162 \mathrm{~m}$ to $1502 \mathrm{~m}$. Most long dams are located in the southern mountainous region of Siberia, where the water source is from the North -to-South Water Diversion in Central Asia and North Asia, which is a Quaternary active glacier area. Dams are mostly built on the U-shaped valley carved by glaciers. While in a low height, the dam is rather long, yet it is technically feasible. Reservoirs are slender, and some reservoirs, such as the Bratsk Reservoir, have been built, and can be utilized for water diversion projects. The water diversion project sometimes needs to go through seismic belts, for example, the Great West route of the South-to-North Water Diversion project in China crosses the Kangding-Ganzi seismic belt [26], so earthquake-resistance is an issue the project should be concerned with. At present, the southwest region is building and preparing for the construction of several 200 meters or even 300 meters high dams located in areas with high seismic intensity. Dam anti-seismic technology in China is well developed, ranking as the forefront in the world.

Tunnel: The water transfer project needs to build a large number of long tunnels, large-diameter tunnels, deep-buried tunnels and multiple-track tunnels. With the principle of shortest distance for water transfer, the plan adopts the multiroute water transfer scheme to reduce the number and mileage of multiple-track tunnels. According to the author's original plan, Shaluli Mountain tunnel along the Great West route of China's South-to-North Water Diversion is $103 \mathrm{~km}$ as the longest, and the high limit of tunnel diameter is 14.44 meters, the maximum hard rock TBM (tunnel boring machine) diameter. At present, the tunneling technology is progressing rapidly. The diameter of the shield tunneling machine from German Herrnekncht AG is $19.35 \mathrm{~m}$, and the maximum length of a single tunnel is 283 kilometers [27]. The longest tunnel to be built is $115 \mathrm{~km}$ for the Eurasia Grassland water transfer project. Along the Great West route of China's South-to-North water diversion project, there are high mountains, deep valleys and many deep-buried tunnels. It also has a high probability of rock bursts during tunnel boring, so precautions should be taken. The lithology affects the progress of TBM's tunnel boring progress. The sandstone and slate are main rocks along the Great West Line of the South-to-North
Water Diversion Project. The sandstone is of medium hardness, while the slate's hardness is poor; both of them have good strata for boring. Mainly located at Western Sayan Mountain in Russia, tunnels along the upper route of the Turan Plain is very long. The rock there is mainly made up of mud and sand shale, siliceous schist, quartzite and limestone, etc. The hardness of quartzite is high, which will affect the progress of tunnel boring. The vertical movement of the crust also has an impact on the boring of the tunnel. The Great West route of China's South-to-North Water Diversion is designed to bore tunnels in the southeastern margin of the Qinghai-Tibet Plateau. It needs to cross the active fault. The area where the crustal ascending speed changes violently is just at the section of the Nujiang River, as well as the section where many short tunnels are built at the southern foot of the Nianqing Tanggula Mountain. The overall influence of the crust lifting on the diversion project is not too great.

Canal: In addition to the water supply function, the Eurasia Canal and its branches are the core structures of the water transfer project and important channels for grain transport of Eurasian Grassland expected to increase in the future. To build canals crossing over the mountain and inland waterway with steep longitudinal slopes is the difficult part of the project. Therefore, navigation locks need to be built for waterways and aqueducts need to be built for canals. Constructed between 1817-1924 by the United States, the Erie Canal is $584 \mathrm{~km}$ long, with 83 locks. Yao Yan in the Yuan dynasty proposed to build the Luan River channel project navigable to Shangdu, but Guo Shoujing believed it was too difficult to implement. The author believes that with modern engineering technology, the Luan River can be built into a Class-III channel navigable for six months. The longitudinal slope from Zhenglanqi on the Luan River to the Guojia Village is characterized by a gentle upstream slope and steep downstream slope. The river is $110 \mathrm{~km}$ from the boundary of Inner Mongolia and Hebei Province, where the river bed's elevation reduces from $1,310 \mathrm{~m}$ to $1,152 \mathrm{~m}$; the river runs $200 \mathrm{~km}$ from the boundary to Guojiacun, where the river bed's elevation declines from $1,152 \mathrm{~m}$ to $781 \mathrm{~m}$. According to the current maximum single level lock lift of 45.2 meters (Three Gorges Dam's fourth lock on the Yangtze River), four locks need to be built at the upper section and nine locks at the lower section. On the mainstream of the Luan River, totally twenty-nine classes of locks need to be built to make the channel navigable, including sixteen locks from Guajiacun to the estuary. Locks should be constructed in some areas along the Eurasia Canal and its branches, such as the section from Balkhash Lake to Chuili Ridge, the section of Heilongjiang-Liaoning Canal going through from Sanka, Huma County, Heilongjiang Province to Beijiang passing over the Xiao Xinan Range, the north-western foot of Langshan Mountain connecting Gobi waterway and the Eurasian Canal, and the Manshuitan-Yellow River steep slope channel.

Trunk canal and aqueduct: The trunk channel of the water diversion project has the characteristics of wide distribution and 
long line. The trunk canal is designed as wide and shallow cross sections; sections with intensive evaporation need to be built as narrow and deep cross sections; the trunk canal going through the Loess Plateau is required to take biological and physical slop protection measures to prevent water and soil erosion, and a large number of aqueducts need to be built to cross the gullies of the Loess Plateau. There are many flowing sand hills at Kumtag Desert on the border between Gansu and Xinjiang, so that a small number of sections need to lower the water transfer route and construct aqueducts across sand hills. In the intensive evaporation area, an inverted siphon culvert needs to be built for water transfer. The traditional karez canal needs to be dug in order to reduce evaporation, to resist wind damage and sand burial. Main aqueducts to be built for the Eurasian Grassland water transfer project include: two river-crossing aqueducts at Yenisei River and Chulym River, aqueducts in the western and eastern parts of Yabulai Mountain to pass through moving sand dunes, and many gully aqueducts and Huangshui aqueducts on the Loess Plateau. Aqueducts of the Loess Plateau's trunk channels are mostly located along the western bank of the Yellow River. There are many aqueducts designed and most aqueducts are short ones with large water flow capacity. Though with rather easy engineering technology, yet it will be more difficult if IVClass navigation canals need to be built. At an elevation of 1,730, the Huangshui aqueduct has the largest volume of water flow, so that it needs to build a long aqueduct with large width and length. It is the bottleneck project of the trunk channel for water transport in engineering technology. Aqueducts in the western and eastern parts of the Yabulai Mountain are at an elevation of $1,430 \mathrm{~m}$ and $1,420 \mathrm{~m}$ respectively (Figure 3 ). They are in the key section of the Eurasia Canal, requiring the wide aqueduct for the standard of II-Class channel, which is suitable for double track navigable aqueducts. Girder bridge aqueducts can be built according to the different terrains. Aqueducts at Yenisei River and Chulym River need to go across wide and deep river valley. It is feasible technically in engineering to build a girder bridge with the highest pier of $137 \mathrm{~m}$.

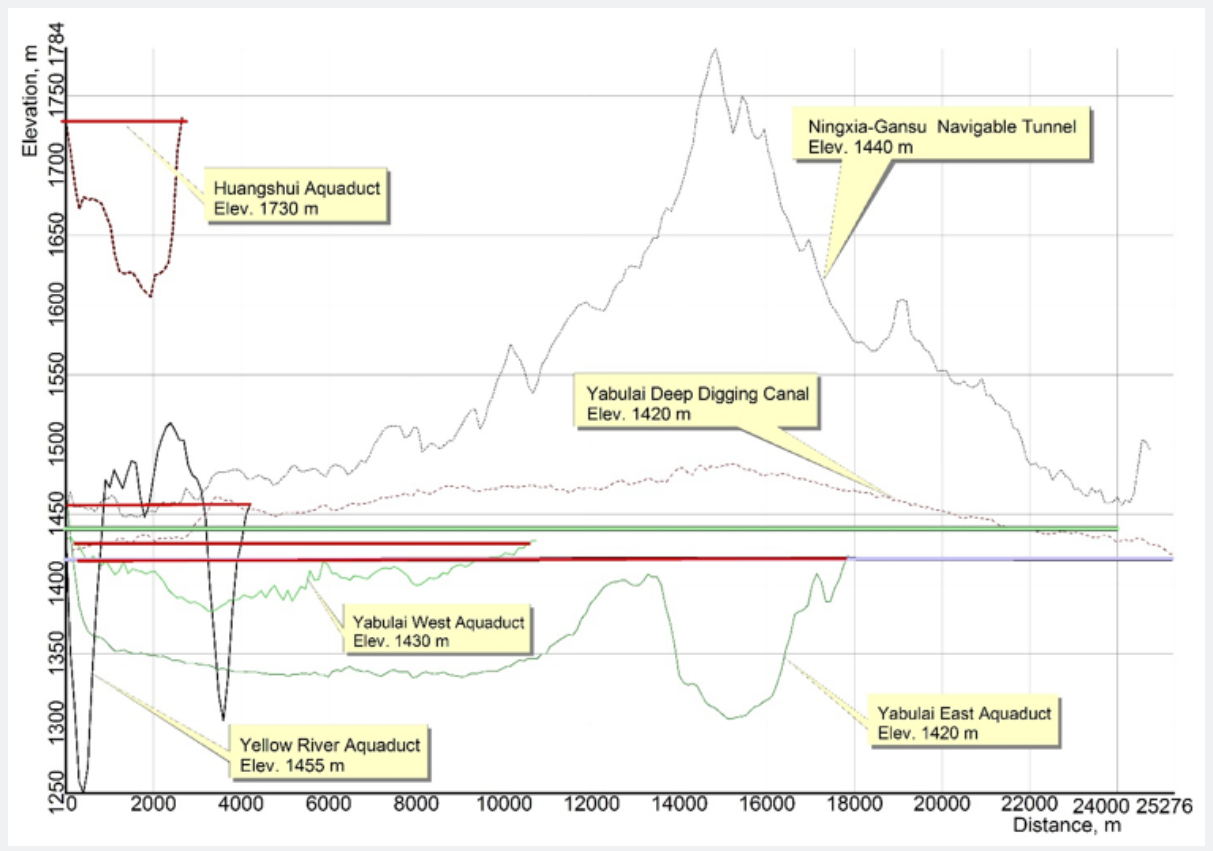

Figure 3: Topographic profiles of Eurasian Grassland water transfer's main canal projects.

\section{Favorable physical and social factors}

The traffic condition along the planned water transfer routes has been improved. With the economic development of Northwest China, the traffic construction speeds up, China's traffic condition along the South-to-North Water Transfer route has achieved great improvement, which provides a convenient traffic condition for the construction of the Great West Route. Lhasa - Linzhi Railway, Chengdu - Lanzhou Railway, Chengdu Ya'an Railway and Chongqing - Lanzhou Railway will be finished soon, while Sichuan-Tibet Railway, Golmud - Korla (QinghaiXinjiang) Railway, Inner Mongolia - Xinjiang Railway are under construction. The South Xinjiang Railway loop has gone as far as
Hetian City. Inner Mongolia and Northwestern China's highway and express highway networks are well developed in the past two decades. Existing Siberian and Central Asia railway system built by the former Soviet Union can facilitate the water transfer project of the Eurasian Grassland.

A flexible investment and financing model for the project construction can be adopted. With the current economic situation of a labor surplus, excess capital and construction capacity in China, water infrastructure construction enjoys a strong engineering technical force. Dominated by the government, large amounts of capital can be raised by taking a flexible investment and financing model approach, such as BOT 
(build-operate-transfer), BT (build-transfer), TOT (Transferoperate-transfer), PPP (public-private partnership), ABS(Assetbacked Securities) and so on. A large amount of funds can be raised by issuing shares and national bonds. AIIB (Asian Infrastructure Investment Bank) can provide funding for the investment as well. Under unified planning and the design of the water transfer project, taking an overall management of project funds, constructing the project from small to large, from easy to difficult, by stages and in groups, and by segmented construction, the construction speed is able to be improved and the quality of the project can be ensured.

By utilizing current water conservancy projects and natural conditions, the amount of construction can be reduced. For example, the existing reservoirs can be used directly to transfer water, upstream reservoirs can increase the regulating storage; the groundwater funnel can be recharged and be used as an underground reservoir to supply water. Making full use of the existing reservoirs, natural river courses, groundwater aquifers, field pools and underground reservoirs to store the water transferred to the destination; relying on the existing oasis, making full use of existing karez canals, trunk canal, branch canal, sub-lateral canal and lateral canal system to deploy water resources, the cost of water distribution can be saved obviously.

Based on modern agricultural technology, the conditions of reclamation can be improved and utilization efficiency of water resources can be enhanced. In the process of irrigation reclamation, advanced agricultural technology will be employed extensively, such as the promotion of soil improvement technology, drip irrigation with plastic film mulching and integration of water and fertilizer; implementation of agricultural mechanization, cultivating improved crop varieties, adopting an advanced cultivation pattern; establishment of a wind protection shelter forest system, and applying prevention and control technology for hail and frost disasters, so that the reclamation conditions get improved, and the level of agricultural modernization in the reclamation area and water use efficiency will be significantly improved.

Table 4: Total cost estimation, units: 100 million CNY.
Making an overall plan of the use of transferred water and local runoff. Taking the water transferred as the main water source, coordinating the runoff of destination area and local mountainous regions, to jointly utilize the surface water, groundwater, transferred water, and reservoir water storage to increase the guarantee level of water supply, so that drought resisting and high and stable crop yields can be achieved.

The amount of transferred water can be reduced by the multiplier effect of evaporation. Inland basin irrigation can increase local precipitation by evaporation. After long-term water transfer in the future, due to the multiplier effect of oasis evaporation, the precipitation in the downwind area can be increased so that the extraneous water can be recycled, and the water transfer volume can be gradually reduced. It is estimated that $72 \%$ of the precipitation in Northern China comes from the evaporation of water vapor in Eurasia during the growing season, and the evaporation multiplier of the Yellow River basin is 1.724 [28,29].

\section{Technical Economic Analysis}

\section{Cost benefit analysis}

According to the author's estimate for L2, the multiple track length of the project is 24,945 kilometers and the total investment is about 3,357.1 billion Yuan. The cost of the multiple-track construction is 134.58 million Yuan per kilometer. The water transferred is 212.92 billion cubic meters at the unit cost of 15.77 Yuan per cubic meter. According to the construction cost of 134.58 million Yuan per kilometer, Eurasian Grassland's interbasin water transfer project needs a total investment of 8,931.56 billion Yuan, of which the Great West line of China's South-toNorth Water Diversion (L2) ranks the largest investment, followed by Kulunda-Turan west line (L8) and Turgay-Turan east line (L7) with investment of 1,759.31 billion Yuan and 1,323.73 billion Yuan respectively. Unit cost of water transferred among the nine projects range from 2.96 to $35.39 \mathrm{CNY} / \mathrm{m}^{3}$, with an average of $10.02 \mathrm{CNY} / \mathrm{m}^{3}$.

\begin{tabular}{|c|c|c|c|c|c|c|c|}
\hline Destination Regions & $\begin{array}{c}\text { Cost of Water } \\
\text { Transfer }\end{array}$ & $\begin{array}{c}\text { Branch Canal } \\
\text { Cost }\end{array}$ & $\begin{array}{c}\text { Cost of } \\
\text { Farmland Pools }\end{array}$ & $\begin{array}{c}\text { Cost of Drip } \\
\text { Irrigation }\end{array}$ & $\begin{array}{c}\text { Shadow Price } \\
\text { of Waste Land }\end{array}$ & $\begin{array}{c}\text { Total Cost } \\
\text { Income/ Cost } \\
\text { Ratio }\end{array}$ \\
\hline North China Plain & 5713 & 482 & 0 & 0 & 0 & 6195 & 3.94 \\
\hline Northwest China & 33571 & 2193 & 19910 & 5044 & 11109 & 71827 & 2.87 \\
\hline Qaidam Basin & 1943 & 167 & 962 & 320 & 213 & 3605 & 2.13 \\
\hline Northeast Plain & 3366 & 275 & 141 & 226 & 1050 & 5058 & 5.06 \\
\hline Hulun Lake & 3030 & 259 & 549 & 1211 & 3407 & 8456 & 2.07 \\
\hline Gobi Desert & 3383 & 217 & 1409 & 737 & 1266 & 7013 & 1.94 \\
\hline Turgay-Turan east & 13237 & 743 & 24235 & 4696 & 10466 & 53377 & 2.93 \\
\hline Kulunda-Turan west & 17593 & 731 & 7298 & 3502 & 10455 & 39579 & 2.51 \\
\hline Caspian and Aral & 7479 & 584 & 20506 & 4856 & 10383 & 43809 & 3.8 \\
\hline Total & 89316 & 5651 & 75011 & 20592 & 48350 & 238919 & 3 \\
\hline
\end{tabular}


The benefit of the Eurasian Grassland's inter-basin water transfer reclamation with drip irrigation is huge, which can be divided into direct benefits and indirect benefits. Direct benefits can be used to calculate the internal rate of return (IRR), including 4 benefits of reclamation, power generation, shipping, and water sales. Thus by 30 years, the Eurasian Grassland's inter-basin water transfer irrigation and reclamation project will achieve a total income of 71,675.98 billion Yuan and the total income-total investment ratio is 3.00 (Table 4).

Total investment of the Eurasia Grassland's inter-basin water transfer irrigation and reclamation project is 23,891.9 billion Yuan, sub-categories' investment from large to small in turn is the investment of water transfer project, the cost of field pools, the expense of purchasing arable wasteland, the investment of drip irrigation equipment, and branch canal. In terms of a thirty-year construction period, the annual static investment is 796.3 billion Yuan. During China's thirteenth Five-Year Plan, it is schemed to invest 15 trillion Yuan for traffic construction, 2.43 trillion Yuan for water conservancy investment, sum up to an annual investment of 3.486 trillion Yuan. While the investment of the Eurasian Grassland's water transfer project only accounts for $22.8 \%$ of the annual investment in traffic and water conservancy. Therefore, China has the ability to afford all of the investment of the water transfer project.

Table 5: Cost benefit accounting, 100 million CNY.

\begin{tabular}{|c|c|c|c|c|c|c|}
\hline Destination Regions & $\begin{array}{l}\text { Land Reclamation } \\
\text { Income }\end{array}$ & $\begin{array}{l}\text { Water Selling } \\
\text { Income }\end{array}$ & $\begin{array}{l}\text { Hydro-Power } \\
\text { Income }\end{array}$ & $\begin{array}{l}\text { Canal Transport } \\
\text { Income }\end{array}$ & $\begin{array}{c}\text { Total } \\
\text { Income }\end{array}$ & IRR \\
\hline North China Plain & 0 & 22637 & 379 & 1409 & 24425 & $10.74 \%$ \\
\hline Northwest China & 114096 & 39604 & 46035 & 6164 & 205899 & $7.92 \%$ \\
\hline Qaidam Basin & 5164 & 1021 & 939 & 564 & 7688 & $19.11 \%$ \\
\hline Northeast Plain & 3846 & 19716 & 203 & 1818 & 25582 & $22.25 \%$ \\
\hline Hulun Lake & 13444 & 2986 & 81 & 977 & 17488 & $20.87 \%$ \\
\hline Gobi Desert & 10363 & 2468 & 227 & 521 & 13579 & $17.54 \%$ \\
\hline Turgay-Turan east & 119612 & 29978 & 4684 & 2314 & 156588 & $9.63 \%$ \\
\hline Kulunda-Turan west & 61169 & 30187 & 5533 & 2361 & 99249 & $7.08 \%$ \\
\hline Caspian and Aral & 113861 & 46923 & 2791 & 2688 & 166262 & $16.35 \%$ \\
\hline Total & 441554 & 195520 & 60870 & 18815 & 716760 & $8.79 \%$ \\
\hline
\end{tabular}

The internal rate of return (IRR) and net present value (NPV) of the project can be calculated according to the estimated total investment and total income. Five water transfer projects include the North China Plain, the Qaidam Basin, the Northeast China Plain, the Hulun Lake and the Gobi Desert, the construction periods are calculated by ten years. The Caspian and Aral lowland are calculated by twenty years. Three water transfer projects including Inner Mongolia in the Great Northwest Region, TurgayTuran east line and Kulunda-Turan west line are calculated by thirty years. $4.9 \%$ is taken for the discount rate, and $0.5 \%$ of the total cost is taken for management and maintenance cost after construction in the calculation. The calculated overall IRR is $8.79 \%$. The highest IRR is between $19 \%$ and $23 \%$ for Northeast China Plain, Hulun Lake and Qaidam Basin, followed by the IRR between $16 \%$ and $18 \%$ for the Gobi Desert and Caspian and Aral lowland. The IRR is $7.92 \%$ for Inner Mongolia of the Northwestern China. The IRR of Kulunda-Turan west line is $7.08 \%$, ranking the lowest of the nine projects (Table 5). Taking all the factors into comprehensive consideration, IRR is determined by unit cost, income-cost ratio, construction period and investment scale. For long-distance water transfer project, it needs large funds, long construction period and has lower IRR.

\section{Multiple indirect benefits}

As the necessary path of the Silk Road, the Tea Road and the Jade Road in history, the Eurasian Grassland is a vital place for economic interaction between the east and the west in ancient times. Ten countries in the study area are located on the Silk Road, including six major destination countries, China, Russia, Mongolia, Kazakhstan, Uzbekistan, Turkmenistan, and four upstream countries including Kyrgyzstan, Tajikistan, Afghanistan, and Iran. According to the IMF, the total amount of GDP in ten water transfer countries in 2016 is $14,086.6$ billion US dollars, the total population is 1,705.68 million, and the total land area is 34.57 million square kilometers, accounting for $18.2 \%, 23.3 \%$ and $25.9 \%$ of the world's total respectively. In this area, the per capita GDP is 10,138 USD, which is $81.5 \%$ of the world's average; the population density is 54.8 per square kilometer, which is $90.0 \%$ of the world's average. Ten countries of the Eurasian Grassland are generally middle-income countries in the critical period of economic development.

The water transfer project will provide these ten countries on the Eurasian Grassland with multiple indirect benefits, including economic, social and ecological benefits. The main economic benefits are to maintain rapid economic growth, the water transfer project can increase China's annual GDP growth by 1.426 percentage points, thus extending the middle and high-speed development period by thirty years or more. It also helps the development of the border area, breaks the bottleneck of scarce water resources and sparse population to achieve balanced development; strengthens the agricultural foundation 
to secure the global food supply, makes the six destination countries the world's major food exporters; promotes the highefficient water-saving irrigation technology, and is beneficial evidently to flood and drought resistance. All of the nine projects' irrigation and reclamation area accounts for $58.6 \%$ of the world's current irrigation area; developing inland navigation can greatly save the transportation cost. Via the mouth of the Luan River, the transportation distance by inland waterway from Shanghai to the middle of the eastern session of the Eurasian Canal is only $22.6 \%$ of the transportation distance by sea from Shanghai to New Orleans, in the USA. The main social benefits include Eurasian Canal is the modern Silk Road suitable to start cruise lines, promoting the development of cultural tourism along the line; reclamation by agricultural immigrants can improve poverty alleviation and increase farmers' income. The project can strengthen the national unity and consolidate the frontier of each country, solve the issue of water resources shortage and eliminate international disputes on water resources. It can improve the international relationship between source and destination countries, enhance their international political influence, expand the living space and strengthen the comprehensive national power of the destination countries; The project also helps to realize the transformation from traditional society into the society of industrialization and agricultural modernization, to end with the thousands of years of conflict between agrarian and nomadic ethnics. Bonded with the water transfer project, the ten Eurasian countries can act jointly to form the Eurasian Economic Union gradually. The main ecological benefits include: to increase the oasis' carbon sink and improve the value of ecological services [30]; to promote the diffusion and migration of industries and population to reduce the smog pollution in densely populated areas; to enhance the ecological environment of the destination areas and restore the aquatic ecological environment in the destination areas; admission of ecological immigrants from the mountainous region can relieve the population pressure on the mountainous environment, effectively prevent and control soil erosion at the mountainous regions.

Given the comprehensive evaluation of many factors, such as technology, economy, ecology and international relations, we can determine the priority of the nine projects. Of the five projects in China, the North-to-South Water Diversion on the Northeast China Plain is critical for revitalizing the economy in Northeast China while the West line and Great West line of the South-to-North Water Diversion are core projects for the development of Northwestern China, and it can greatly promote the economic development in countries along the Silk Road by the construction of the Eurasian canal. Therefore, these two projects should take the priority. The Qaidam Basin's South-toNorth water diversion project and the Hulun Lake's North-toSouth water diversion projects are in small investment scale yet with high IRR. Both are located in remote areas, and the latter covers the three countries of China, Mongolia and Russia, so they can be constructed in the second stage; the middle line extension of the South-to-North water diversion project can increase the amount of transferred water, and it is also conducive to the development of inland navigation in North China Plain, which can be the third stage in project construction. Among the four foreign country dominating water diversion projects, the Caspian and Aral lowland line and the Turgay-Turan east line have the characteristics of large volume of transferred water and higher IRR. At the core of the Silk Road, the two projects involve the three major powers of Russia, Kazakhstan and Uzbekistan. As they can be connected with China's Great West line, they should be constructed at the first stage; Gobi Desert's North-toSouth water transfer project in Mongolia has great significance for Mongolian economic development and involvement to the Silk Road Economic Belt, so it can be listed to the second stage; the lower line of Central Asia North-to-South project, KulundaTuran west, is actually is the extension of to the Turgay-Turan east line, which can give a thorough solution to Central Asia's water resource crisis, it should be in the third stage [31].

\section{Conclusion and Discussion}

The main conclusions of this study are as follows:

i. The Eurasian Grassland water transfer project is conducive to promoting the comprehensive development of regional economy and has great potential for development. The destination area of this water transfer scheme involves the vast majority of low-elevation plain areas of the Eurasian Grassland, which can effectively break the bottleneck of local water resource and release great development potential and promote the economic development of the whole region.

ii. The project is huge, and the engineering technology is feasible. Huge as the Eurasian Grassland water transfer project, yet it is feasible under the world's water conservancy engineering level at present. China has played a leading role in the key technology of water diversion projects, such as dams, tunnels, main canals, canals locks and aqueducts; Russia is equipped with advanced water conservancy construction in the frigid zone, which is a perfect compensation for China.

iii. It generates significant economic benefits and the cost is bearable by China's national strength. The water transfer project is the engine of economic growth for ten countries on the Eurasian Grassland in the next thirty years. At present, China is experiencing industrial overcapacity where largescale construction of transportation networks has been basically completed. So, it is a good time to plan and construct the water diversion project of the Eurasian Grassland. The water transfer project has enormous economic benefits and its investment scale is smaller compared with the traffic investment and is within Chinese comprehensive national strength for construction. 
iv. It has multiple benefits and profound historical significance. The water transfer project can help establish the world's big granary in the central area of the Eurasia continent, reshapes the world's map of self-sufficient rate of food; joint exploitation of cross-border water resources can achieve multi-national economic development, set a model for the development of frontier under international cooperation; Eurasian canal will promote greatly the cultural communication between the East and West with far-reaching historical significance.

v. Involving countries along the Silk Road, the project has great practical significance. The water transfer and canal construction can be an important project choice for the "Belt and Road Initiative". It has great practical significance to strengthen the economic cooperation between China and Russia and Central Asian countries with the investment from AIIB (Asian Infrastructure Investment Bank).

The Eurasian Grassland water transfer and canal project is invested and constructed jointly by many countries, so international relations should be the focus of future discussion, and the specific issues should be studied in depth are as follows.

i. To determine the international water rights and to solve the problem of international water resources redistribution. Besides the ten countries on the Eurasian Grassland, there may also have conflicts of water rights in some countries on the South Asian Subcontinent and Indo-China Peninsula. So, we should first clarify the water rights and land property rights before redistributing water resources, so as to avoid international dispute.

ii. International investment and financing models for the water transfer project. The model of international development, investment and management is worth discussing. International projects of water transfer can be funded by AIIB, and more flexible investment and funding models, such as international investment cooperation, international BT (build-transfer), and international asset securitization.

iii. Joint regulating of water resources. Upstream and downstream water resources allocation is the core content of water transfer project, so international cooperation should be strengthened by making water distribution program, signing intergovernmental agreement to jointly regulate water resources to solve the water dispute between upstream and downstream countries.

iv. Scientific management of water resources. The water transfer project is a huge one, involving ten countries and more than one-hundred rivers, so the scientific view of development should be adopted to strengthen scientific management and introduce advanced intelligent and modern management mode in order to maximize water transfer efficiency and achieve sustainable and efficient use of water resources.

v. Establish common goals of development, to strengthen international cooperation. The countries concerned should put aside the differences and constraints of the social system and ideology, establish partnership, complement each other's advantages and make efficient use of water and land resources through cooperation among all partners; to ensure the global food supply and achieve the common goal of a harmonious world, all of the countries concerned should cohere to meet mutual benefit and pursue common development.

\section{References}

1. Yang L (2003) Overview of Foreign Water Transfer Projects. Water Resources Development Research (6): 55-56.

2. Wang G, Ouyang Q, et al. (2009) World Water Transfer Project. Beijing: China Science Publishing and Media Ltd.

3. Beets M (2014) NAWAPA XXI Will 'Bend' the Water Cycle; Save Calif Texas. Executive Intelligence Review - Economics, pp. 24-31.

4. Baker MM (2013) Anti-NAWAPA Water Policy Means Food Emergency. Executive Intelligence Review -- Economics, pp. 23-26.

5. Deniston B (2013a) Expanding NAWAPA XXI: Weather Modification to Stop Starvation. Executive Intelligence Review - Feature, pp. 49-57.

6. Deniston B (2013b) The Nuclear-Thermonuclear NAWAPA XXI. Executive Intelligence Review - Feature, pp. 4-15.

7. Kirsch M (2013) Nuclear NAWAPA XXI, Desalination, and the New Economy. Executive Intelligence Review- Feature, pp. 4-19.

8. Fang Y (2005) Foreign Inter-basin Water Diversion Project and its Ecological Environment Impact. Yangtze River (10): 9-10.

9. Erdi G, Xu Z, Cao Y, Zhenwei X, Yinbai C (1984) Issues of the Water Transfer from Soviet Siberia to Central Asia and Kazakhstan. Haihe Water Resources (S2): 68-72.

10. Su Z, Jiang W (1982) Overview of the Water Transfer Projects in Foreign Countries. World Agriculture (2): 34-37.

11. Geshenko HC (1984) Soviet Water Conservancy Construction Tasks and Development Prospects-Large-scale inter-basin water transfer project status. Journal of Geography (3): 6-10.

12. Malkewa O, Yuan Z (1982) Design of Regional Redistribution of Water Resources. Journal of Geography (3): 29-32.

13. Shao H, Yan D, Hongyuan S, Dingzhong Y (1984) The Soviet Union's Water Transfer Project Planning. Haihe Water Resources (s2): 49-55.

14.Zhang D, Wei C (1986) Soviet Union's Water Transfer Project. China Water Resources (6): 42-44.

15. Liang S (2015) Urbanization in China: Resources Bottleneck and Corresponding Strategies. Beijing: China Agricultural Press, pp. 423-450.

16. Liang S (2013a) A joint water diversion plan for China. Journal American Water Works Association 105(5): E264-E277.

17. Zheng P, Ji S, Zhang X, et al (2015) Reflections on the Water Transfer from the Yalu Zangbu River and the Nu Jiang to the Northwest Arid Area. Water Conservancy and Hydropower Construction (4): 96-99.

18. Wang X, Shi K, Yue C, et al. (2016) The Feasibility of Inter-basin Water Transfer in Xinjiang: A preliminary study on the feasibility of the water 
transfer from the $\mathrm{Nu}$ Jiang into Xinjiang province. Journal of Water Resources and Water Engineering 27(3): 38-142.

19. Van de Ent RJ, Savenije HHG, Schaefli B, Dunne SCS (2010) Origin and fate of atmospheric moisture over continents. Water Resources Research 46(9): 201-210.

20. Lieth H, Whitaker RH, Wang Y, et al. (1985) The Primary Productivity of Biology. Beijing: China Science Publishing and Media Ltd.

21. Hijmans RJ, Cameron S, Parra J (2005) World Clim version1. Berkeley: the Museum of Vertebrate Zoology, University of California, in collaboration with Peter Jones and Andrew Jarvis (CIAT), and with Karen Richardson (Rainforest CRC).

22. Wilkinson K, von Zabern M, Scherzer J (2014) Report No. 44, GRDC Report Series, Global Freshwater Fluxes into the World Oceans. Koblenz国Global Runoff Data Centre, Federal Institute of Hydrology (BfG)

23. Farr TG, Kobrick M (2000) Shuttle Radar Topography Mission produces a wealth of data. Eos Transactions American Geophysical Union 81(48): 583-585.

24. Trabucco A, Zomer RJ (2009) Global Aridity Index (Global-Aridity) and Global Potential Evapo-Transpiration (Global-PET) Geospatial Database. Washington, DC: CGIAR Consortium for Spatial Information.
25. Liang S (2013b) The Development Prospects of the Agricultural Land Reserves in the Combined Central and West Lines of the South-toNorth Water Transfer Project. Water Resources Development Research (12): $15-24$

26. Fu M, Yang S (1994) Atlas of the People's Republic of China. Beijing: China Cartographic Publishing House 1994: 8

27. Deng M (2016) The In--depth Analysis of the core technology of the TBM Cluster Construction of the Deep-buried Super-long Water Tunnel. Chinese Journal of Geotechnical Engineering 38(4): 578-587.

28. Keys P.W, van de Ent RJ, Gordon LJ, Hoff H, Nikoli R, et al. (2012) Analyzing precipitation-sheds to understand the vulnerability of rainfall dependent regions. Biogeosciences 9(2): 733-746.

29. Ellison D, Futter M, Bishop K (2012) On the forest cover-water yield debate: from demand- to supply-side thinking. Global Change Biology 18(3): 806-820.

30. Li Y, Ge Y, Liu A, et al. (2014) Study on the Agricultural Ecological Compensation Mechanism on the Basis of the Carbon Sink of Grain Crops. Issues in Agricultural Economics 35(10): 33-40.

31. Kelly RP (1982) North American Water and Power Alliance, NAWAPA Plan Can Work. La Verne, California: Energy Report, National Energy Research and Information Institute, June/July 1982.

\section{Your next submission with Juniper Publishers will reach you the below assets}

- Quality Editorial service

- Swift Peer Review

- Reprints availability

- E-prints Service

- Manuscript Podcast for convenient understanding

- Global attainment for your research

- Manuscript accessibility in different formats

( Pdf, E-pub, Full Text, Audio)

- Unceasing customer service

Track the below URL for one-step submission https://juniperpublishers.com/online-submission.php 